\title{
Range and conservation updates for the Critically Endangered blue-eyed black lemur Eulemur flavifrons and the Vulnerable black lemur Eulemur macaco
}

\author{
Jen C. Tinsman, Caitlin L. Eschmann, J. Sedera Solofondranohatra \\ Jocelyn Romelius Ralainirina, Marc Holderied and Gráinne McCabe
}

\begin{abstract}
The Critically Endangered blue-eyed black lemur Eulemur flavifrons of north-western Madagascar is one of the most threatened primates. The majority of research and conservation efforts for the species have been restricted to the Sahamalaza Peninsula but there are unstudied and unprotected populations farther inland. The dearth of information regarding the transition between $E$. flavifrons and its parapatric sister species, the Vulnerable black lemur Eulemur macaco, and the possibility of a hybrid population complicates conservation planning for both species. We surveyed 29 forest fragments across both species' ranges to investigate the boundary between the taxa, whether hybrids persist, and the threats to lemurs in the region. We found E. flavifrons in six fragments and E. macaco in 17. We never observed E. flavifrons and E. macaco in the same location and we found no conclusive evidence of hybrids. Three fragments in which E. flavifrons was present were north of the Andranomalaza River, which had previously been considered the barrier between the two species. Based on these observations and a literature review, we provide updated ranges, increasing the extent of occurrence (EOO) of $E$. flavifrons by $28.7 \%$ and reducing the $\mathrm{EOO}$ of $E$. macaco by $44.5 \%$. We also evaluate the capacity of protected areas to conserve these lemurs. We recommend additional surveys and the implementation of an education programme in this region to help conserve both species.
\end{abstract}

Keywords Black lemur, blue-eyed black lemur, geographical range, Manongarivo Special Reserve, Sahamalaza-Iles Radama National Park, species distribution

JEN C. Tinsman $¥$ (Corresponding author, (1) orcid.org/0000-0003-2452-4573) Columbia University, 116th St and Broadway, New York, New York 10027, USA. E-mail jen.tinsman@gmail.com

Cattuin L. Eschmann† (Corresponding author) and MarC Holderied School of Biological Sciences, University of Bristol, Bristol, UK

E-mail caitlin.eschmann@gmail.com

J. Sedera Solofondranohatra and Jocelyn Romelius Ralainirina University of Antananarivo, Antananarivo, Madagascar

Gráinne McCabe Bristol Zoological Society, Bristol, UK

${ }^{*}$ Also at: New York Consortium on Evolutionary Primatology, New York, USA $†$ Also at: Bristol Zoological Society, College Road, Clifton, Bristol, UK

\$These authors contributed equally to this work.

Received 13 November 2017. Revision requested 8 February 2018.

Accepted 13 June 2018. First published online 5 August 2019.
Supplementary material for this article is available at https://doi.org/10.1017/So030605318000868

\section{Introduction}

Aagascar, a biodiversity hotspot (Myers et al., 2000), 1 is home to $>100$ endemic species of lemurs, accounting for $>20 \%$ of global primate diversity; however, $94 \%$ of lemur species are threatened by hunting and deforestation (Schwitzer et al., 2014). One of the species most affected is the Critically Endangered blue-eyed black lemur Eulemur flavifrons, which is subject to poaching and habitat loss as a result of slash-and-burn rice cultivation (tavy), logging and livestock rearing (Andrianjakarivelo, 2004; Seiler et al., 2010; Andriaholinirina et al., 2014a). The population of the blue-eyed black lemur declined by $>80 \%$ during 1990-2014 (Andriaholinirina et al., 2014a).

Estimates of $E$. flavifrons numbers have focused mainly on the protected population in the Ankarafa Forest of Sahamalaza-Iles Radama National Park, where there are estimated to be $60-130$ individuals $/ \mathrm{km}^{2}$ (Schwitzer et al., 2006; Volampeno et al., 2010). Surveys of the isolated fragments where E. flavifrons occurs farther inland found much lower densities, with a mean of 24 individuals $/ \mathrm{km}^{2}$ (Andrianjakarivelo, 2004). Based on these surveys there are only an estimated 2,780-6,950 individuals remaining (Schwitzer et al., 2006). A population viability analysis concluded that the Ankarafa population, which is the largest remaining, could be extirpated by 2026 (Volampeno et al., 2015). The vulnerability of $E$. flavifrons is partially attributable to its unique habitat; the species occurs only in the transitional, subtropical forest between Madagascar's western dry deciduous forests and the humid evergreen rainforests of the east (Schwitzer et al., 2007). The plant, amphibian, reptile and mammal communities of the Sahamalaza Peninsula include endemic species that occur nowhere else on Madagascar (Birkinshaw, 2004; Schwitzer et al., 2006; Penny et al., 2017).

Although not confined to the Sahamalaza Peninsula, E. flavifrons has one of the smallest geographical ranges of the genus Eulemur (Volampeno et al., 2010). Its estimated extent of occurrence (EOO; i.e. the smallest, continuous 


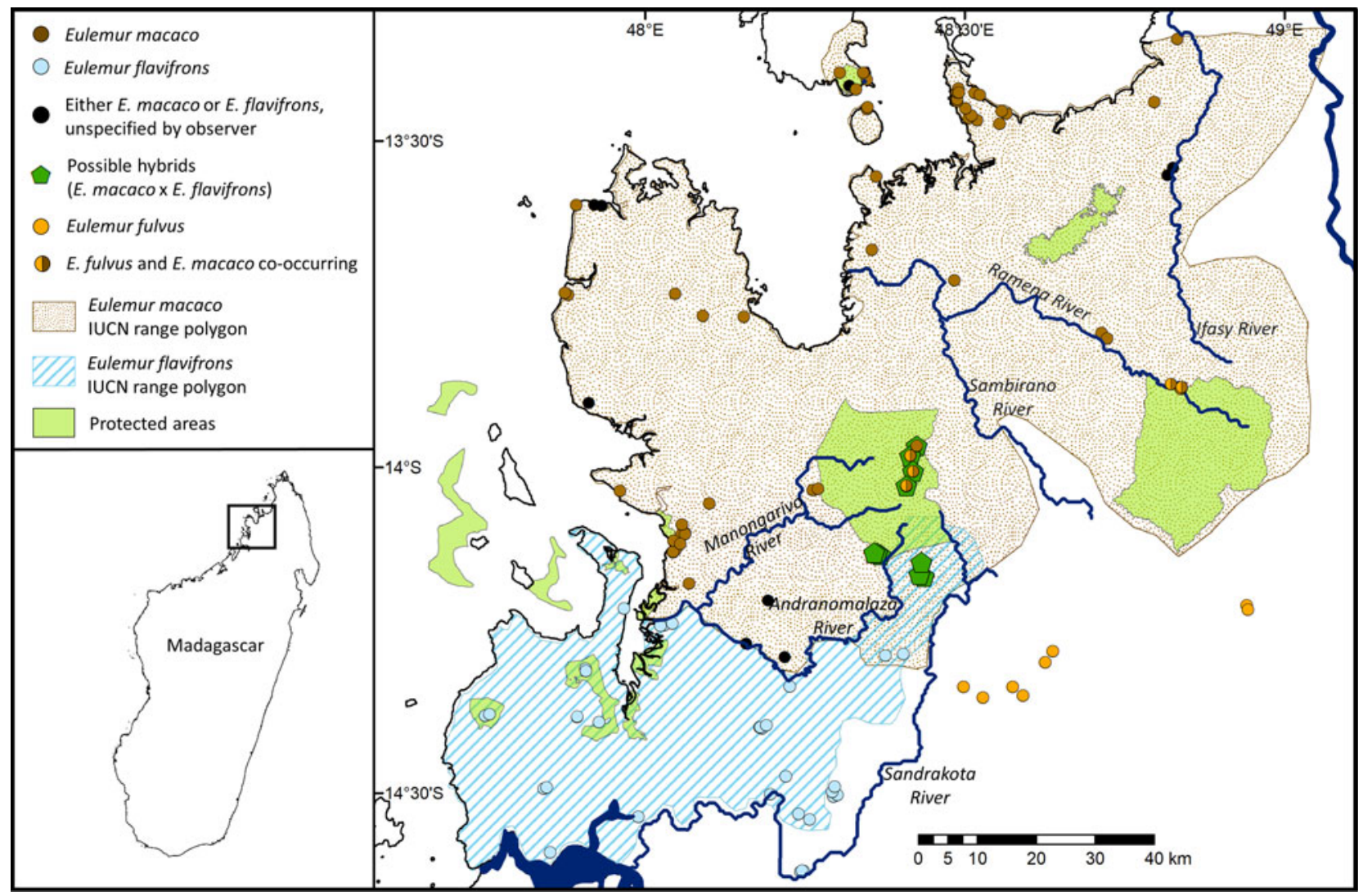

FIG. 1 Previous extent of occurrence polygons for Eulemur macaco and Eulemur flavifrons, from IUCN (used with permission). All known occurrence records for E. flavifrons, E. macaco and putative hybrids, and for Eulemur fulvus, in the area are noted.

area encompassing all known or projected occurrences of a species; IUCN, 2001) is $<2,700 \mathrm{~km}^{2}$ (Andriaholinirina et al., 2014a). Its area of occupancy (AOO; i.e. the area of suitable habitat that is actually occupied within a species' EOO; IUCN, 2001) must be even smaller, although it had not been estimated previously.

The EOO of E. flavifrons is bounded by the Mozambique Channel to the west and the Maevarano River to the south (Koenders et al., 1985; Petter \& Andriatsarafara, 1987; Randriatahina \& Rabarivola, 2004; Schwitzer \& Lork, 2004; Andriaholinirina et al., 2014a; Fig. 1). It extends east to the Sandrakota River and Manongarivo Special Reserve, which comprises 32,000 ha of protected Sambirano rainforest (MEF \& MNP, 2010). Previous studies have identified the Andranomalaza River, also called the Maitsomalaza in the local Sakalava dialect, as the boundary between E. flavifrons and its parapatric sister species, the black lemur Eulemur macaco (Koenders et al., 1985; Andriaholinirina et al., 2014a). However, there is conflicting evidence regarding whether the lemurs between the Andranomalaza River and the more northern Manongarivo River are hybrids, intermediate-appearing forms on a phenotypic cline, or typical members of either species (Meyers et al., 1989; Rabarivola et al., 1991; Andrianjakarivelo, 2004; Randriatahina \& Rabarivola, 2004).
The first report of phenotypic variation was by Meyers et al. (1989), who observed two distinct groups of lemurs unlike typical E. flavifrons or E. macaco. The first group was at Beraty: individuals had light brown eyes and short ruffs of hair around their ears, characteristics that are intermediate between E. flavifrons and E. macaco. The second group was at Ambodivoahangy: individuals had darker eyes and redder coats than is typical of Sahamalaza E. flavifrons. However, when Andrianjakarivelo (2004) visited Ambodivoahangy he found animals that 'greatly resembled' E. flavifrons. Goodman and Schütz (2000) surveyed the eastern slopes of Manongarivo Special Reserve, north of Ambodivoahangy, and identified groups containing both E. macaco and 'hybrid' individuals but did not detail their criteria for these distinctions. Their assessment was complicated by the presence of E. fulvus in that area, which may be perceived as having a reddish coat (Goodman \& Schütz, 2000).

Updated assessments of the lemurs in this region are necessary to establish effective conservation initiatives for these two species (Rakotonirina et al., 2011, 2014). They could also improve estimates of the species' ranges, especially considering the area has not been assessed since 2004 (Schwitzer et al., 2014). We investigated the presence and phenotypes of Eulemur species from Sahamalaza-Iles Radama National Park to Manongarivo Special Reserve, 


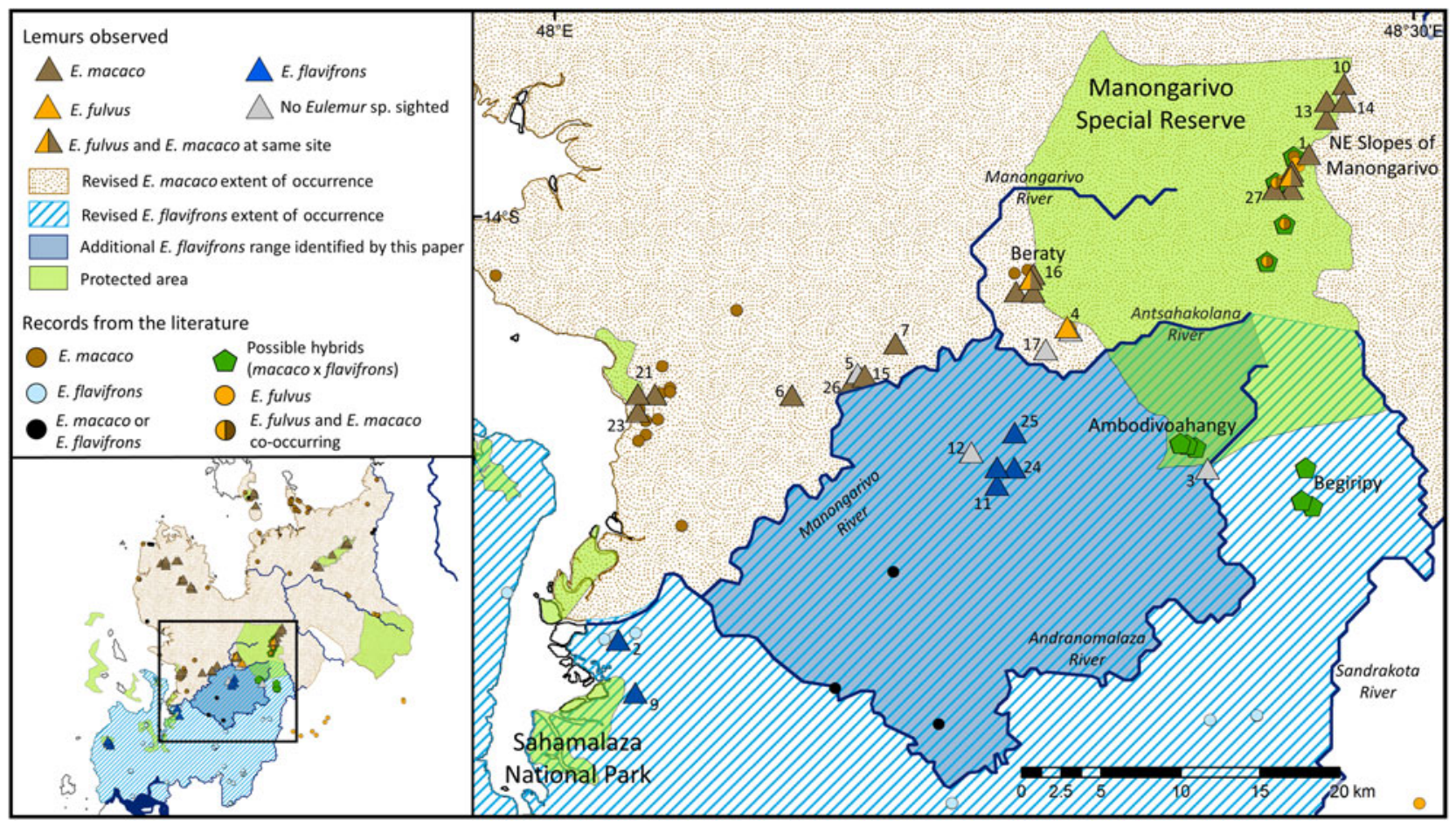

FIG. 2 Updated extent of occurrence polygons for E. flavifrons and E. macaco based on field work conducted in this study (triangles) and previous published studies (circles). Numbers correspond to numbering of forest fragments in Table 1.

and the threats to their survival, to (1) establish the continued existence of E. flavifrons outside protected habitat, (2) locate the purported contact zone between E. flavifrons and E. macaco, and (3) understand anthropogenic pressures in and around the protected areas in this region. We provide updated EOOs and new AOOs for both species, and report on the status of the lemurs between the Manongarivo and Andranomalaza Rivers.

\section{Methods}

We conducted surveys during June-September and NovemberDecember 2015, June 2016 and April-June 2017. To evaluate possible barriers between E. flavifrons and E. macaco we worked eastwards from the coast near Maromandia $\left(14^{\circ} 12^{\prime} 11.9^{\prime \prime} \mathrm{S}, 48^{\circ} \mathrm{O} 4^{\prime}\right.$ 54.1" $\left.\mathrm{E}\right)$ to the north-eastern slopes of Manongarivo Special Reserve ( $14^{\circ}$ oo of $^{\prime} .8^{\prime \prime} \mathrm{S}, 48^{\circ} 22^{\prime}$ $47.3^{\prime \prime} \mathrm{E}$ ), focusing our efforts around the Andranomalaza and Manongarivo rivers. We visited eight sites within and 10 outside the Reserve (Fig. 2) and 11 other sites throughout the region to record threats to lemur survival and to observe typical members of both species (Figs $2 \& 3$ ). We searched for lemurs for up to 7 days at each site, recording an absence if we could not find lemurs after a week of diurnal surveys led by a local person who worked in the forest. We walked the interior of each fragment, relying on paths when possible, until we heard lemur vocalizations or movement.
We followed the lemurs until they settled down to sleep, which enabled us to observe them more closely. We recorded locations of all observed Eulemur spp. with a GPS and noted key morphological features (eye colour, presence of ruffs) to distinguish between E. flavifrons and E. macaco. Evidence of tavy, livestock incursions, traps and hunting was also noted.

In addition to field surveys we reviewed the literature for occurrence records of E. flavifrons and E. macaco. We searched four online databases (ReBioMa, Manis, VertNet and GBIF) for Eulemur spp. records. All relevant articles published in Lemur News, Madagascar Conservation and Development, Primate Conservation and Malagasy Nature were scanned visually for geographical coordinates. We also conducted several searches in Google Scholar using combinations of the following terms: Eulemur macaco, Eulemur flavifrons, GPS, occurrence, coordinates, and range. These articles, databases and our field efforts yielded 119 unique records for E. flavifrons and 182 for E. macaco (Supplementary Table 1). New EOOs were determined by comparing these records to the river catchments in this region. River data were downloaded from WWF's HydroSHEDS project (Lehner et al., 2008).

To approximate AOOs for these species we used these occurrence records to construct ecological niche models. Points were thinned to no closer than $2.5 \mathrm{~km}$ apart, to reduce spatial autocorrelation (Kramer-Schadt et al., 2013). We downloaded environmental data related to an arboreal 


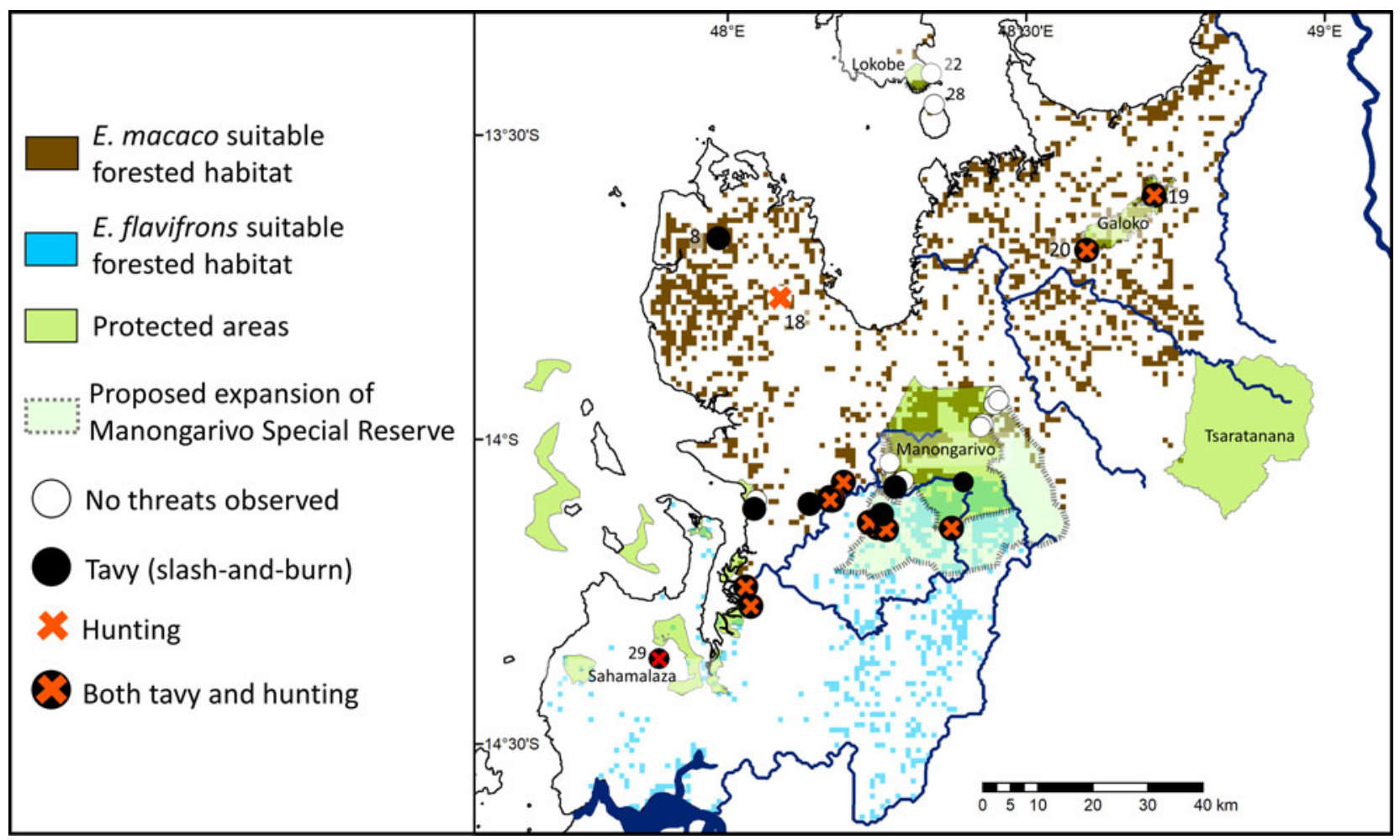

FIG. 3 Extent of remaining suitable habitat for E. flavifrons and E. macaco, and threats observed throughout the study area. Numbers correspond to numbering of forest fragments in Table 1.

life history from WorldClim, CliMond, SoilGrids, WorldGrids, and CIRCAD (see Supplementary Table 2 for data types and sources). Only variables with relatively low correlation to each other $\left(\left|R^{2}\right|<0.85\right.$; mean $\left.\left|R^{2}\right|=0.38\right)$ were included in analyses to reduce model overfitting (Dormann et al., 2013; Pearson et al., 2014). We constructed niche models with MaxEnt 3.4.1 (Phillips et al., 2017) using parameters identified with ENMeval (Muscarella et al., 2014).

We used a 10\% training threshold to turn models into a binary prediction of 1 (suitable habitat) or o (unsuitable). The model for each species was then limited to its EOO and the most recent forest cover estimate available (Vieilledent et al., 2018). They were resampled to $2 \mathrm{~km}^{2}$ resolution, which is the IUCN standard for AOO, before the area was calculated.

\section{Results}

We observed E. flavifrons in six of the 29 forest fragments surveyed (21\% of sites; Table 1 ), and E. macaco in 17 fragments $(59 \%)$. We observed E. fulvus at four sites, twice on its own and twice co-occurring with E. macaco. At four of the sites (14\%) we found no individuals of any Eulemur species, and we never observed E. flavifrons and E. macaco in the same forest fragment. The lemurs we observed in previously unstudied areas near Antsahabilahy and along the Maherivaratra mountain range had pale eyes and no ruffs and appeared to be E. flavifrons, despite occurring north of the Andranomalaza River, within the IUCN-identified EOO for E. macaco (Plate 1, Fig. 2; Andriaholinirina et al., 2014b).

The only lemurs we observed that did not resemble typical members of either species were a few male lemurs at Beraty in Manongarivo Special Reserve (Plate 1). These males had shorter ruffs than other male E. macaco we had seen previously. Given that the females all resembled typical E. macaco and these individuals occurred at the southern end of their range, they could simply be clinal variants. Thus, we tentatively identify them as E. macaco. On the north-eastern slopes of the Reserve, at another possible hybrid site we visited, we saw only typical E. macaco and E. fulvus. We were unable to locate any lemurs at Ambodivoahangy, the last possible hybrid site, despite extensive searching.

Although we observed E. flavifrons north of the Andranomalaza River, we never observed the species north of the Manongarivo River, nor did we observe E. macaco south of the Manongarivo. We therefore propose that the Manongarivo and its tributary, the Antsahakolana River, form the boundary between the two species (Fig. 2). We generated a new EOO polygon for E. flavifrons based on these findings, increasing its EOO by $29 \%$, from 2,700 to $3,475 \mathrm{~km}^{2}$ (Andriaholinirina et al., 2014a; Fig. 2).

In addition to changing the southern boundary of $E$. $m a$ caco to the Manongarivo River, we concluded the species is bounded in the east by the Ifasy River, as our literature search revealed no records east of the river (Figs 1 \& 2). In 


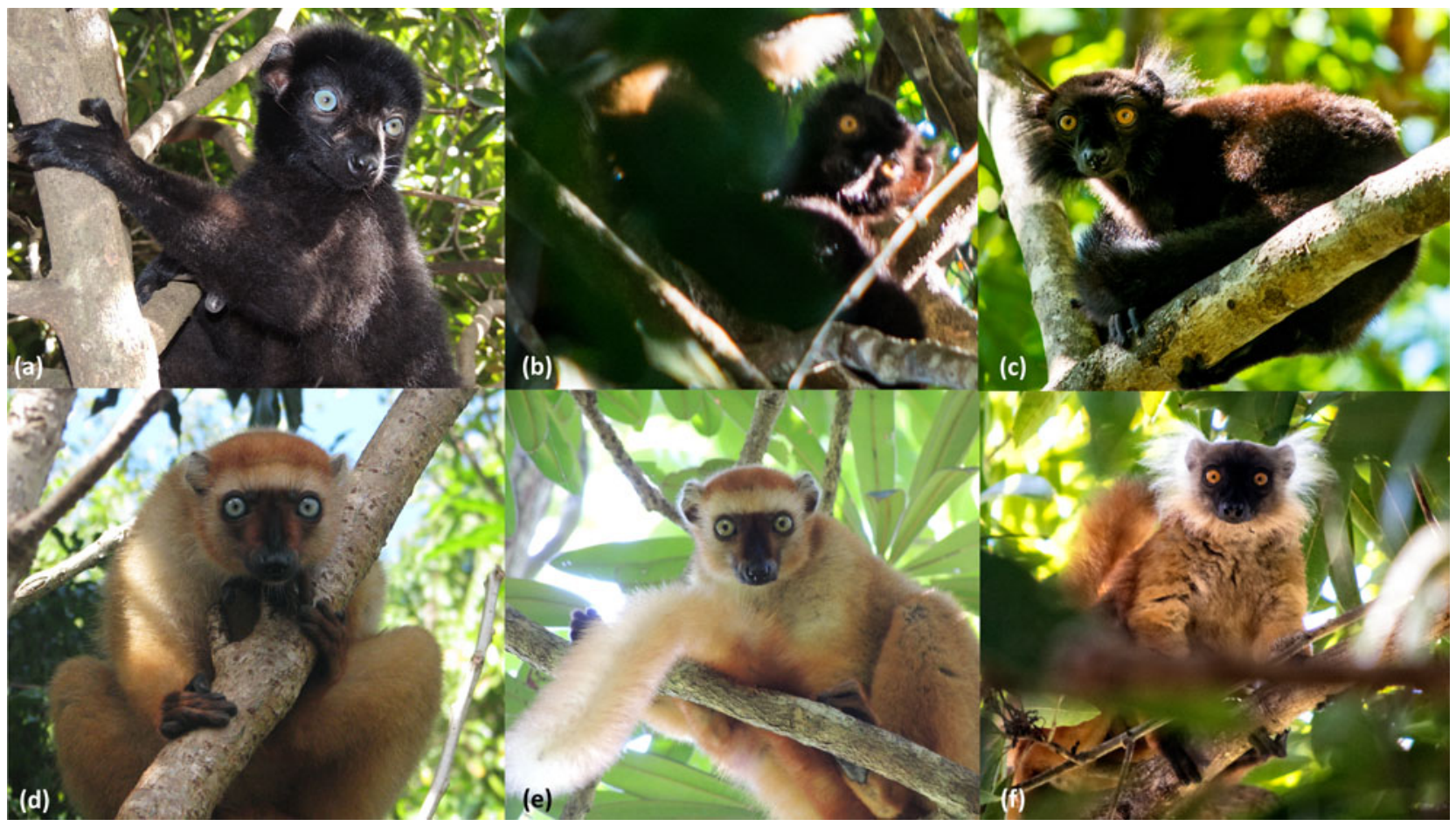

Plate 1 Typical Eulemur flavifrons (left: (a) male and (d) female) and E. macaco (right: (c) male and (f) female), with a possible intermediate form from Beraty (centre: (b) male), with similar eye colour but a shorter ruff compared to E. macaco. (e) Putative E. flavifrons (female) from Antsahabilahy A (Table 1), with pale eyes and no ruff.

the south-east E. macaco was bounded by the Tsaratanana Reserve for similar reasons, although such limited surveys have been conducted in this region that this should be considered a low-confidence boundary. This revision reduces the $\mathrm{EOO}$ for E. macaco to $6,510 \mathrm{~km}^{2}$, only $55 \%$ of the previous estimate of $11,740 \mathrm{~km}^{2}$ (Andriaholinirina et al., 2014b). When these EOOs are limited to suitable habitat and remaining forest cover, E. macaco has an AOO of $\leq 1,992 \mathrm{~km}^{2}$ and E. flavifrons of $\leq 884 \mathrm{~km}^{2}$.

Throughout their ranges these lemurs endure extensive habitat disturbance and other anthropogenic threats. Subsistence hunting and tavy were present in a majority of the 29 surveyed locations $(69 \%, n=20$; Table 1), including $100 \%$ of the E. flavifrons locations we visited. Only nine sites had no evidence of hunting or tavy. Eight were within protected areas managed by Madagascar National Parks and one was a heavily trafficked site on Nosy Komba where local people procure lemurs to entertain tourists. There was evidence of hunting, tavy or both in all four protected areas managed by an NGO, whereas there were threats present in only three of the 11 sites managed by Madagascar National Parks (Table 1).

\section{Discussion}

Although these changes in EOO do not warrant immediate adjustments to the species' IUCN Red List status, the range contraction for E. macaco is of concern and suggests the need for updated population estimates (Volampeno et al., 2010, 2015). A census of the newly identified population of E. flavifrons at Maherivaratra and Antsahabilahy is also needed urgently. The area it occupies south of Manongarivo Special Reserve is part of the largest continuous forest in this species' AOO (Fig. 3), and this population may be the largest remaining without any protection.

We were unable to confirm the ongoing presence of hybrid lemurs, despite visiting three of the four sites where they had been reported previously (Supplementary Table 1). Surveys between the headwaters of the Antsahakolana and Sandrakota Rivers are needed to determine a more accurate boundary between E. flavifrons and E. macaco and to collect genetic samples to examine any potential hybridization.

During our surveys we encountered traps, hunters, livestock, and/or tavy in 20 of the 29 study sites (Table 1), indicating that disturbance is an ongoing concern both inside and outside protected areas. The recent pressures on these lemur populations were described by our local guide for the Bemabaza fragment, where we observed fewer than a dozen E. macaco in 2016. He informed us that there had been nearly 100 lemurs 5 years previously but most of these had been wiped out by hunting. This increased pressure may be partly a result of cultural shifts. This region was traditionally home to the Sakalava people, for whom lemur consumption is taboo (Ramanantsoa, 1976; Harpet et al., 2000); however, there has been a recent influx of 
TABLE 1 Presence/absence of lemurs and threats to their survival recorded in surveys of forest fragments in Madagascar (Figs 2 \& 3) conducted during 2015-2017.

\begin{tabular}{|c|c|c|c|c|c|c|c|}
\hline \multicolumn{2}{|c|}{ Forest fragment } & \multirow{2}{*}{$\frac{\text { Year }}{2016}$} & \multirow{2}{*}{$\begin{array}{l}\text { Location } \\
13^{\circ} 58^{\prime} 1.74^{\prime \prime} \mathrm{S}, 48^{\circ} 26^{\prime} 3.16^{\prime \prime} \mathrm{E}\end{array}$} & \multirow{2}{*}{$\begin{array}{l}\text { Protected } \\
\text { area }^{1}\end{array}$} & \multirow{2}{*}{$\begin{array}{l}\begin{array}{l}\text { Eulemur } \\
\text { species }\end{array} \\
\text { E. fulvus }\end{array}$} & \multirow{2}{*}{$\begin{array}{l}\text { Traps or evi- } \\
\text { dence of hunting } \\
\text { No }\end{array}$} & \multirow{2}{*}{$\frac{\text { Tavy }}{\text { No }}$} \\
\hline 1 & Ambavanambahatra & & & & & & \\
\hline 2 & Ambodimanga & 2015 & $14^{\circ} 14^{\prime} 21.12^{\prime \prime} \mathrm{S}, 48^{\circ} 2^{\prime} 15.36^{\prime \prime} \mathrm{E}$ & & E. flavifrons & Yes & Yes \\
\hline 3 & Ambodivoahangy & 2015 & $14^{\circ} 8^{\prime} 22.56^{\prime \prime} \mathrm{S}, 48^{\circ} 22^{\prime} 57.00^{\prime \prime} \mathrm{E}$ & MNP & & Yes & Yes \\
\hline 4 & Ambohitsara & 2016 & $14^{\circ} 3^{\prime} 36.70^{\prime \prime} \mathrm{S}, 48^{\circ} 18^{\prime} 7.00^{\prime \prime} \mathrm{E}$ & MNP & E. fulvus & No & No \\
\hline 5 & Ampapanabe & 2015 & $14^{\circ} 5^{\prime} 28.68^{\prime \prime} \mathrm{S}, 48^{\circ} 10^{\prime} 40.08^{\prime \prime} \mathrm{E}$ & & & Yes & Yes \\
\hline 6 & Analafady & 2015 & $14^{\circ} 6^{\prime} 5.76^{\prime \prime} \mathrm{S}, 48^{\circ} 8^{\prime} 39.48^{\prime \prime} \mathrm{E}$ & & E. macaco & No & Yes \\
\hline 7 & Andokobe & 2015 & $14^{\circ} 3^{\prime} 57.24^{\prime \prime} \mathrm{S}, 48^{\circ} 12^{\prime} 1.02^{\prime \prime} \mathrm{E}$ & & E. macaco & Yes & Yes \\
\hline 8 & Andranomatavy & 2015 & $13^{\circ} 39^{\prime} 59.37^{\prime \prime} \mathrm{S}, 47^{\circ} 59^{\prime} 15.87^{\prime \prime} \mathrm{E}$ & NGO & E. macaco & Yes & Yes \\
\hline 9 & Angodrahely & 2017 & $14^{\circ} 16^{\prime} 14.88^{\prime \prime} \mathrm{S}, 48^{\circ} 2^{\prime} 47.40^{\prime \prime} \mathrm{E}$ & & E. flavifrons & Yes & Yes \\
\hline 10 & Ankazomena & 2016 & $13^{\circ} 55^{\prime} 20.86^{\prime \prime} \mathrm{S}, 48^{\circ} 27^{\prime} 21.13^{\prime \prime} \mathrm{E}$ & MNP & E. macaco & No & No \\
\hline 11 & Antsahabilahy A & 2015 & $14^{\circ} 8^{\prime} 24.00^{\prime \prime} \mathrm{S}, 48^{\circ} 15^{\prime} 25.56^{\prime \prime} \mathrm{E}$ & & E. flavifrons & Yes & Yes \\
\hline 12 & Antsahabilahy B & 2015 & $14^{\circ} 7^{\prime} 53.40^{\prime \prime} \mathrm{S}, 48^{\circ} 14^{\prime} 41.50^{\prime \prime} \mathrm{E}$ & & & Yes & Yes \\
\hline 13 & Befalafa & 2015 & $13^{\circ} 56^{\prime} 9.24^{\prime \prime} \mathrm{S}, 48^{\circ} 27^{\prime} 10.80^{\prime \prime} \mathrm{E}$ & MNP & E. macaco & No & No \\
\hline 14 & Bekiritsana & 2015 & $13^{\circ} 55^{\prime} 45.37^{\prime \prime} \mathrm{S}, 48^{\circ} 27^{\prime} 35.71^{\prime \prime} \mathrm{E}$ & MNP & E. macaco & No & Yes \\
\hline 15 & Bemabaza & 2015 & $14^{\circ} 5^{\prime} 42.72^{\prime \prime} \mathrm{S}, 48^{\circ} 10^{\prime} 59.16^{\prime \prime} \mathrm{E}$ & & E. macaco & Yes & Yes \\
\hline 16 & Beraty & 2015 & $14^{\circ} 1^{\prime} 57.72^{\prime \prime} \mathrm{S}, 48^{\circ} 16^{\prime} 42.24^{\prime \prime} \mathrm{E}$ & MNP & $\begin{array}{l}\text { E. macaco, } \\
\text { E. fulvus }\end{array}$ & No & No \\
\hline 17 & Bevazimba & 2016 & $14^{\circ} 4^{\prime} 21.36^{\prime \prime} \mathrm{S}, 48^{\circ} 17^{\prime} 15.36^{\prime \prime} \mathrm{E}$ & & & No & Yes \\
\hline 18 & Bongomirahavavy & 2015 & $13^{\circ} 45^{\prime} 48.06^{\prime \prime} \mathrm{S}, 48^{\circ} 5^{\prime} 29.44^{\prime \prime} \mathrm{E}$ & NGO & E. macaco & Yes & No \\
\hline 19 & Galoko & 2015 & $13^{\circ} 35^{\prime} 25.55^{\prime \prime} \mathrm{S}, 48^{\circ} 43^{\prime} 0.45^{\prime \prime} \mathrm{E}$ & NGO & E. macaco & Yes & Yes \\
\hline 20 & Kalobinono & 2015 & $13^{\circ} 40^{\prime} 53.70^{\prime \prime} \mathrm{S}, 48^{\circ} 36^{\prime} 17.13^{\prime \prime} \mathrm{E}$ & NGO & E. macaco & Yes & Yes \\
\hline 21 & Kapany & 2015 & $14^{\circ} 5^{\prime} 46.32^{\prime \prime} \mathrm{S}, 48^{\circ} 3^{\prime} 17.28^{\prime \prime} \mathrm{E}$ & MNP & E. macaco & No & No \\
\hline 22 & Lokobe & 2015 & $13^{\circ} 23^{\prime} 33.68^{\prime \prime} \mathrm{S}, 48^{\circ} 20^{\prime} 29.13^{\prime \prime} \mathrm{E}$ & MNP & E. macaco & No & No \\
\hline 23 & Mahadera & 2016 & $14^{\circ} 6^{\prime} 37.80^{\prime \prime} \mathrm{S}, 48^{\circ} 3^{\prime} 6.12^{\prime \prime} \mathrm{E}$ & & E. macaco & No & Yes \\
\hline 24 & Maherivaratra A & 2015 & $14^{\circ} 8^{\prime} 33.72^{\prime \prime} \mathrm{S}, 48^{\circ} 16^{\prime} 23.52^{\prime \prime} \mathrm{E}$ & & E. flavifrons & Yes & Yes \\
\hline 25 & Maherivaratra B & 2016 & $14^{\circ} 7^{\prime} 4.44^{\prime \prime} \mathrm{S}, 48^{\circ} 15^{\prime} 58.32^{\prime \prime} \mathrm{E}$ & & E. flavifrons & No & Yes \\
\hline 26 & Mandriranabe & 2015 & $14^{\circ} 5^{\prime} 42.00^{\prime \prime} \mathrm{S}, 48^{\circ} 10^{\prime} 41.16^{\prime \prime} \mathrm{E}$ & & E. macaco & Yes & Yes \\
\hline 27 & Manongarivo $^{2}$ & 2015 & $13^{\circ} 58^{\prime} 21.00^{\prime \prime} \mathrm{S}, 48^{\circ} 25^{\prime} 46.92^{\prime \prime} \mathrm{E}$ & MNP & $\begin{array}{l}\text { E. macaco, } \\
\text { E. fulvus }\end{array}$ & No & No \\
\hline 28 & Nosy Komba & 2015 & $13^{\circ} 26^{\prime} 38.70^{\prime \prime} \mathrm{S}, 48^{\circ} 20^{\prime} 50.38^{\prime \prime} \mathrm{E}$ & & E. macaco & No & No \\
\hline 29 & Sahamalaza (Ankarafa) & 2015 & $14^{\circ} 23^{\prime} 05.60^{\prime \prime} \mathrm{S}, 47^{\circ} 45^{\prime} 56.90^{\prime \prime} \mathrm{E}$ & MNP & E. flavifrons & Yes & Yes \\
\hline
\end{tabular}

${ }^{2} \mathrm{MNP}$, protected area managed by Madagascar National Parks; NGO, protected area managed by the Missouri Botanical Garden.

${ }^{2}$ E. macaco and E. fulvus were resting together in the same tree.

Tsimihety people (Wilson, 1971; Feeley-Harnik, 1980), who consume primates (Golden \& Comaroff, 2015).

Given the level of habitat exploitation and hunting we observed in this region we suggest a multifaceted approach to conserving both species, as well as protecting the remaining forest fragments. In the near term additional surveys are needed to estimate population numbers accurately (Salmona et al., 2014), evaluate habitat quality in these fragments (Irwin et al., 2005) and assess the impact the various threats reported here have had on E. flavifrons and E. macaco (Rakotonirina et al., 2011; Ravaloharimanitra et al., 2011).

In general, we observed fewer threats to lemurs in areas managed by Madagascar National Parks than in those managed by NGOs (Table 1); however, this dichotomy is confounded by a few factors. Well-protected sites within Manongarivo Special Reserve had one of two factors in their favour: frequent park staff presence or steep terrain unsuitable for rice cultivation or cattle ranching. All NGO-managed protected areas we visited were closer to human settlements, arable, and unpatrolled by enforcement authorities.

The newly reported population of E. flavifrons is in relatively accessible forest, but park patrols or on-site staff would help protect these animals. These options would be a possibility if the previously proposed expansion of Manongarivo Special Reserve happens (MEFT \& MEM, 2008). This expansion would include the newly identified populations of E. flavifrons reported here and the largest block of suitable forest remaining for this species (Fig. 3).

However, increasing the size of the Reserve will not achieve protection for these lemurs until the ongoing problems at its current borders are addressed (Gardner et al., 2018). The remote, low-lying areas in and south of the Reserve, including Ambodivoahangy and the proposed area of expansion, are experiencing ongoing forest loss, and the tavy and poaching we report here have been a problem for the Reserve since at least 2010 (MEF \& MNP, 2010). 
These incursions are in part because of the lack of boundary markers around the Reserve and the difficulty of patrolling remote areas. Additional funding to address these concerns, coupled with increased researcher presence in this region, would help to deter deforestation (Seiler et al., 2010; Campera et al., 2017). Poaching is probably driven by the lack of readily available protein in this region; we saw children with kwashiorkor in several of the towns we visited south of the Reserve. In Madagascar domestic meats are generally preferred to bushmeat, and therefore providing chickens or fish stocks to these communities could reduce the poaching pressure on lemurs (Jenkins et al., 2011).

We propose expanding the community-based conservation education initiative of the Association Européenne pour l'Étude et la Conservation des Lémuriens, which increases local support for conservation by teaching $>2,000$ students on the Sahamalaza Peninsula about E. flavifrons, the Association's flagship species (Randriatahina, 2013). We suggest expanding the programme westwards to include the communities near the newly discovered population of E. flavifrons, as well as incorporating aspects of communitybased monitoring into the initiative. Community monitoring schemes have been established elsewhere in Madagascar to engage local people in forest management and the collection of species abundance and demographic data (Rakotonirina et al., 2011; Ravaloharimanitra et al., 2011). Such a programme would promote conservation (Ratsimbazafy, 2003), foster positive attitudes towards the environment (Balestri et al., 2017), and reduce hunting in and around the Reserve (Nadhurou et al., 2017).

Continued surveying of Critically Endangered species such as E. flavifrons is vital for establishing range distributions and identifying anthropogenic pressures on taxa living in increasingly fragmented forests. However, our research and future work should serve as a foundation for urgent, practical efforts to conserve these species. We hope that the identification of new EOOs and AOOs for two priority lemur species, and the threats facing them, will help the Association Européenne pour l'Étude et la Conservation des Lémuriens and community stakeholders as they collaborate to protect the few remaining populations of $E$. flavifrons and E. macaco.

Acknowledgements We thank George Amato, Christoph Schwitzer, the Madagascar Institute for the Conservation of Tropical Environments, and the University of Antananarivo for their support; Tegan Carney, Bruno Ramorasata, Tsimba, Rajaonilazatheophile Solonjatovolaza, Sylviane Volampeno, Jess Williams, and the numerous field guides, volunteers and community leaders who made this work possible; and the anonymous reviewers for their comments. This project was funded by the Alpkit Foundation, the American Society of Mammalogists, Association Européene pour l'Étude et la Conservation des Lémuriens, Conservation International and the Margot Marsh Biodiversity Foundation, the Explorers Club Mamont Scholars Program, Gesellschaft fur Primatologie, IDEA WILD, the John Muir Trust, the Nacey Maggioncalda Foundation, the National
Science Foundation, the New York Consortium in Evolutionary Primatology, Primate Conservation, Inc., and the Rufford Foundation.

Author contributions Field surveys: CLE, JCT, JRR, JSS; literature review, generation of new EOOs and AOOs: JCT; writing: CLE, JCT; research supervision of CLE: $\mathrm{MH}$ and GM.

\section{Conflicts of interest None.}

Ethical standards This research abided by the Oryx guidelines on ethical standards. Permission to conduct this research was obtained from the Ministère de l'Environnement et des Forêts and Madagascar National Parks (Permit No.50/15/MEEF/SG/DGF/DCB.SAP/SCB, No.286/15MEEMF/SG/DGF/DAPT/SCBT, No.55/16/MEEMF/SG/ DGFDAPT/SCBT, No.76/16/ MEEMF/SG/DGFDAPT/SCBT, and No.64/17/MEEF/SG/DGF/DSAP/SCB). This project received Institutional Animal Care and Use Committee approval from Columbia University and the University of Bristol. We complied with all relevant U.S. and Malagasy laws during this project.

\section{References}

Andriaholinirina, N., Baden, A., Blanco, M., Chikhi, L., Cooke, A., Davies, N. et al. (2014a) Eulemur flavifrons. In The IUCN Red List of Threatened Species 2014: e.T8211A16117351. Http://dx.doi.org/10.2305/IUCN.UK.2014-1.RLTS.T8211A16117351.en [accessed 26 March 2017].

Andriaholinirina, N., Baden, A., Blanco, M., Chikhi, L., Cooke, A., Davies, N. et al. (2014b) Eulemur macaco. In The IUCN Red List of Threatened Species 2014: e.T8212A16117639. Http://dx.doi. org/10.2305/IUCN.UK.2014-1.RLTS.T8212A16117639.en [accessed 26 March 2017].

Andrianjakarivelo, V. (2004) Exploration de la Zone en Dehors de la Peninsule Sahamalaza pour l'Evaluation Rapide de la Population $d^{\prime} \mathrm{E}$. m. flavifrons. Unpublished report. Wildlife Conservation Society, Antananarivo, Madagascar.

Balestri, M., Campera, M., Nekaris, K.A.I. \& Donati, G. (2017) Assessment of long-term retention of environmental education lessons given to teachers in rural areas of Madagascar. Applied Environmental Education \& Communication, 16, 298-311.

Birkinshaw, C.R. (2004) Priority areas for plant conservation. Ravintsara, 2, 14-15.

Campera, M., Phelps, M., Besnard, F., Balestri, M., Eppley, T.M., Nijman, V. \& Donati, G. (2017) Does forest management and researchers' presence reduce hunting and forest exploitation by local communities in Tsitongambarika, south-east Madagascar? Oryx, published online 20 November 2017.

Dormann, C.F., Elith, J., Bacher, S., Buchmann, C., Carl, G., Carré, G., Marquéz, J.R., Gruber, B., Lafourcade, B., Leitão, P.J. \& MÜNKEMÚLLER, T. (2013) Collinearity: a review of methods to deal with it and a simulation study evaluating their performance. Ecography, 36, 27-46.

Feeley-Harnik, G. (1980) The Sakalava house (Madagascar). Anthropos, 75, 559-585.

Gardner, C.J., Nicoll, M.E., Birkinshaw, C., Harris, A., Lewis, R.E., Rakotomalala, D. \& Ratsifandrihamanana, A.N. (2018) The rapid expansion of Madagascar's protected area system. Biological Conservation, 220, 29-36.

Golden, C.D. \& Comaroff, J. (2015) The human health and conservation relevance of food taboos in northeastern Madagascar. Ecology and Society, 20, 42.

Goodman, S.M. \& SchUTZ, H. (2000) The lemurs of the northeastern slopes of the Réserve Spéciale de Manongarivo. Lemur News, 5, 30-33. 
Harpet, C., Jeannoda, V. \& Hladik, C.M. (2000) Sites à lémuriens sacrés en pays sakalava, au Nord-Ouest de Madagascar: réactualisation des données et implications dans les programmes de développement et de conservation. Revue d'Ecologie (Terre Vie), 55, 291-295.

Irwin, M.T., Johnson, S.E. \& Wright, P.C. (2005) The state of lemur conservation in south-eastern Madagascar: population and habitat assessments for diurnal and cathemeral lemurs using surveys, satellite imagery and GIS. Oryx, 39, 204-218.

IUCN (2001) 2001 IUCN Red List Categories and Criteria (version 3.1). Http://www.iucnredlist.org/technical-documents/categories-andcriteria/2001-categories-criteria [accessed 10 October 2017].

Jenkins, R.K., Keane, A., Rakotoarivelo, A.R., Rakotomboavonjy, V., Randrianandrianina, F.H. Razafimanahaka, H.J. et al. (2011) Analysis of patterns of bushmeat consumption reveals extensive exploitation of protected species in eastern Madagascar. PLOS ONE, 6, e27570.

Koenders, L., Rumpler, Y., Ratsirarson, J. \& Peyriéras, A. (1985) Lemur macaco flavifrons (Gray, 1867): a rediscovered subspecies of primate. Folia Primatologica, 44, 210-215.

Kramer-Schadt, S., Niedballa, J., Pilgrim, J.D., Schröder, B., Lindenborn, J., Reinfelder, V. et al. (2013) The importance of correcting for sampling bias in MaxEnt species distribution models. Diversity and Distributions, 19, 1366-1379.

Lehner, B., Verdin, K. \& Jarvis, A. (2008) New global hydrography derived from spaceborne elevation data. Eos, Transactions, American Geophysical Union, 89, 93-94.

Meyers, D.M., Rabarivola, C. \& Rumpler, Y. (1989) Distribution and conservation of Sclater's lemur: implications of a morphological cline. Primate Conservation, 10, 77-81.

MeF (Ministere de L'Environnement et des Forets) \& MNP (Madagascar National Parks) (2010) Plan de Sauvegarde Sociale et Environnementale de la Réserve Spéciale Manongarivo. Unpublished report. Antananarivo, Madagascar. Http://documents. worldbank.org/curated/en/280311468300576836/pdf/RP240oV8o FRENC1oBox358336Bo1PUBLIC1.pdf [accessed 29 March 2018].

MEFT (Ministère DE L'EnVIRONNEMENT ET DEs Forêts ET DU TOURISME) \& MEM (MINISTÈRE DE L'ENERGIE ET DES MINES) (2008) Interministerial Order N18633. Unpublished report. Antananarivo, Madagascar. Http://rebioma.net/index.php/en/useful-links/download/cat_view/ 13-les-textes-officielles [accessed 31 March 2018].

Muscarella, R., Galante, P.J., Soley-Guardia, M., Boria, R.A., Kass, J.M., URIARTE, M. et al. (2014) ENMeval: an $R$ package for conducting spatially independent evaluations and estimating optimal model complexity for Maxent ecological niche models. Methods in Ecology and Evolution, 5, 1198-1205.

Myers, N., Mittermeier, R.A., Mittermeier, C.G., Da Fonseca, G.A.B. \& KENT, J. (2000) Biodiversity hotspots for conservation priorities. Nature, 403, 853-858.

Nadhurou, B., Righini, R., Gamba, M., Laiolo, P., Ouledi, A. \& GiAcoma, C. (2017) Effects of human disturbance on the mongoose lemur Eulemur mongoz in Comoros: implications and potential for the conservation of a Critically Endangered species. Oryx, 51, 60-67.

Pearson, R.G., Stanton, J.C., Shoemaker, K.T., AielloLammens, M.E., Ersts, P.J., Horning, N. et al. (2014) Life history and spatial traits predict extinction risk due to climate change. Nature Climate Change, 4, 217-221.

Penny, S.G., Crottini, A., Andreone, F., Bellati, A., Rakotozafy, L.M., Holderied, M.W. et al. (2017) Combining old and new evidence to increase the known biodiversity value of the Sahamalaza Peninsula, Northwest Madagascar. Contributions to Zoology, 86, 273-296.

Petter, J.J. \& Andriatsarafara, F. (1987) Conservation status and distribution of lemurs in the west and northwest of Madagascar. Primate Conservation, 8, 169-171.
Phillips, S.J., Anderson, R.P., Dudík, M., Schapire, R.E. \& Blair, M.E. (2017) Opening the black box: an open-source release of Maxent. Ecography, 40, 887-893.

Rabarivola, C., Meyers, D. \& Rumpler, Y. (1991) Distribution and morphological characters of intermediate forms between the black lemur (Eulemur macaco macaco) and the Sclater's lemurs (E. m. flavifrons). Primates, 32, 269-273.

Rakotonirina, L., Rajaonson, A., Ratolojanahary, T., Rafalimandimby, J., Fanomezantsoa, P., Ramahefasoa, B. et al. (2011) New distributional records and conservation implications for the Critically Endangered greater bamboo lemur Prolemur simus. Folia Primatologica, 82, 118-129.

Rakotonirina, L.H.F., Randriantsara, F., Rakotoarisoa, A.H., Rakotondrabe, R., Razafindramanana, J., Ratsimbazafy, J. \& KING, T. (2014) A preliminary assessment of sifaka (Propithecus) distribution, chromatic variation and conservation in western central Madagascar. Primate Conservation, 28, 43-53.

Ramanantsoa, G.A. (1976) Les lémuriens sacrés de Madagascar. Bulletin de l'Académie Malgache, 52, 153-159.

Randriatahina, G. (2013) Annual Activities Report 2013/Annual Work Plan 2014. Unpublished report. Association Européenne pour l'Étude et la Conservation des Lémuriens, Antananarivo, Madagascar.

Randriatahina, G.H. \& Rabarivola, J.C. (2004) Inventaire des lémuriens dans la partie nord-ouest de Madagascar et distribution d'Eulemur macaco flavifrons. Lemur News, 9, 7-9.

RatsimbazAfy, J. (2003) Lemurs as the most appropriate and best didactic tool for teaching. Lemur News, 8, 19-21.

Ravaloharimanitra, M., Ratoloanahary, T., Rafalimandimby, J., Rajaonson, A., Rakotonirina, L., Rasolofoharivelo, T. et al. (2011) Gathering local knowledge in Madagascar results in a major increase in the known range and number of sites for Critically Endangered greater bamboo lemurs (Prolemur simus). International Journal of Primatology, 32, 776-792.

Salmona, J., Ralantoharijaona, T., Thani, I.M., Rakotonanahary, A., Zaranaina, R., Jan, F. et al. (2014) Daraina sportive lemur (Lepilemur milanoii) density and population size estimates in most of its distribution range: the Loky-Manambato region. Lemur News, 18, 16-19.

Schwitzer, C. \& Lork, A. (2004) Project Sahamalaza-Iles Radama: ein internationales Schutzprojekt für den Sclater's Maki (Eulemur macaco flavifrons GRAY, 1867). Zeitschrift des Kölner Zoo, 47, 75-84.

Schwitzer, C., Mittermeier, R.A., Johnson, S.E., Donati, G., Irwin, M., PeAcock, H. et al. (2014) Averting lemur extinctions amid Madagascar's political crisis. Science, 343, 842-843.

Schwitzer, N., Randriatahina, G.H., Kaumanns, W., Hoffmeister, D. \& Schwitzer, C. (2007) Habitat utilization of blue-eyed black lemurs, Eulemur macaco flavifrons (Gray, 1867), in primary and altered forest fragments. Primate Conservation, 22, 79-87.

Schwitzer, C., Schwitzer, N., Randriatahina, G.H., Rabarivola, C. \& Kaumanns, W. (2006) "Programme Sahamalaza": new perspectives for the in situ and ex situ study and conservation of the blue-eyed black lemur (Eulemur macaco flavifrons) in a fragmented habitat. In Proceedings of the German-Malagasy Research Cooperation in Life and Earth Sciences (eds C. Schwitzer, S. Brandt, O. Ramilijaona, M. Rakotomalala Razanahoera, D. Ackermand, T. Razakamanana \& J.U. Ganzhorn), pp. 135-149. Concept Verlag, Berlin, Germany.

Seiler, M., Randriatahina, G.H. \& Schwitzer, C. (2010) Ongoing threats to lemurs and their habitat inside the Sahamalaza-Iles Radama National Park. Lemur News, 15, 7-9.

Vieilledent, G., Grinand, C., Rakotomalala, F.A., Ranaivosoa, R., Rakotoarijaona, J.-R., Allnutt, T.F. \& Achard, F. (2018) Combining global tree cover loss data with historical national forest- 
cover maps to look at six decades of deforestation and forest fragmentation in Madagascar. Biological Conservation, 222, 189-197.

Volampeno, M.S.N., Masters, J.C. \& Downs, C.T. (2010) A population estimate of blue-eyed black lemurs in Ankarafa Forest, Sahamalaza-Iles Radama National Park, Madagascar. Folia Primatologica, 81, 305-314.
Volampeno, M.S.N., Randriatahina, G.H., Kalle, R., Wilson, A. \& Downs, C.T. (2015) A preliminary population viability analysis of the Critically Endangered blue-eyed black lemur (Eulemur flavifrons). African Journal of Ecology, 53, 419-427.

Wilson, P.J. (1971) Sentimental structure: Tsimihety migration and descent. American Anthropologist, 73, 193-208. 